Original scientific paper - Izvorni znanstveni rad

UDK: 637.112 .2

\title{
Impact of milking frequency on yield, chemical composition and quality of milk in high producing dairy herd
}

doi: 10.15567/mljekarstvo.2017.0307

\begin{abstract}
Paweł Bortacki ${ }^{1}$, Ryszard Kujawiak ${ }^{1}$, Ewa Czerniawska-Piatkowska ${ }^{2}$, Seval Sevgi Kirdar ${ }^{*}$, Jerzy Wójcik², Wilhelm Grzesiak ${ }^{2}$

${ }^{1}$ Sano-Modern Animal Nutrition Sp. z o.o., Lipowa 10, 64-541 Sękowo, Poland

${ }^{2}$ West Pomeranian University of Technology in Szczecin, Department of Ruminant Science, Doktora Judyma 10, 71-460 Szczecin, Poland ${ }^{3}$ Mehmet Akif University Burdur Vocational Higher Education School Food Processing Department Dairy Technology, Istiklal Campus, 15030, Burdur, Turkey

Received - Prispjelo: 03.11.2016. Accepted - Prihvaćeno: 25.05.2017.
\end{abstract}

\begin{abstract}
The aim of this study was to compare daily yield, milk composition and somatic cell count after increasing milking frequency from twice to three times a day. The study also includes the effect of other factors such as: the sequence of lactation $(1,2, \geq 3)$ and the period of lactation (100 days, 101-200 days, 201-300 days, and more than 300 days). In conclusion, it should be noted that increasing the frequency of cow milking had a positive effect both on the milk yield $(\mathrm{P} \leq 0.01)$, causing a substantial increase, as well as on the cytological quality of produced milk. The somatic cell count $(1000 / \mathrm{mL})$ was lower in the group of cows milked three times a day. All the data regarding farming records of this farm came from the SYMLEK system maintained and made available by Polish Federation of Milk Producers and Cattle Breeders (PFHBiPM). Analysis of useful milk traits included: daily yield, fat, protein, dry matter and somatic cell count in milk.
\end{abstract}

Key words: cows, milk, somatic cells, frequency of milking

\section{Introduction}

According to the research conducted thus far, increased multiplicity of milking benefits lactation, stimulates udders, increases cell proliferation in the mammary gland and increases milk yield from 6 to 30 \% (Hale et al., 2003; Wołkowski et al., 2003; Bogucki et al., 2009). As per Capuco et al. (2001) increased frequency of cows milking in the first weeks of lactation results in increased levels of milk yield on average of about $8 \%$ even after reducing the milking times. Bogucki et al. (2011) demonstrated that change in the organization of milking resulted in increase (from 11 to $15 \%$ ) in daily milk yield in the subsequent lactation periods. Early studies illustrated the galactopoietic effect of frequent milking during the entire lactation, with 3 times daily milking increasing milk yield by up to $20 \%$ relative to twice daily milking (Wall and McFadden, 2008). In the work by Czerniawska et al. (2012) it was also noted that introduction of heifers to 4-times a day milking resulted in a lactation yield increase of $3.2 \%$ compared with 2-times. Once-daily milking, compared with the more commonly practiced twice daily milked, reduces milk yield, with losses ranging from 7 to $40 \%$, depending on factors such as parity, breed, and stage of lactation (Stelwagen et al. 2013). Barlowska et al. (2012) found that different milking systems adapted according to the size of the herd as well as with proper technology for milk production on a farm significantly affects quality of milk produced commercially. 
The aim of this study was to compare the performance, composition and quality of milk in a high producing dairy herd in relation to 2-times and 3-times milking frequency.

\section{Materials and methods}

The study was conducted in 2013 in Sano Agrar Institute in Lubin, one of the largest farms in the Wielkopolska region, maintaining highly productive dairy cattle herd made up of Holstein-Friesian breed. The cows were kept in free stall barns (add performance) and fed twice a day with full rations of TMR (Total Mixed Ration), which included corn silage, grass silage, pressed beet pulp, straw as well as molasses and compound feeding stuff (Lactasan 34). Until May 2013 milking was carried out twice a day on the inner rotating platform (carousel) in the milking parlor consisting of 28 stalls. From September 2013 the entire herd was milked three times a day on the outer rotary platform in milking parlor DeLaval consisting of 60 stalls. There was analysed 1572 samples of milk, including 764 in first period and 808 in second period. The study included three lactations, respectively in first 386 and 367, in second 218 and 244, in third and above 160 and 197. Average daily milk yield for herd milked twice a day was $30,90 \mathrm{~kg}$ and for herd milked 3 times a day was $34,77 \mathrm{~kg}$. The cows were under A-4 methodology of milking performance assessment by the International Committee for Animal Recording (ICAR, 2003). All of the data regarding farming records of this farm came from the SYMLEK system maintained and made available by Polish Federation of Milk Producers and Cattle Breeders (PFHBiPM).

Analysis of useful milk traits included: daily yield, fat, protein, dry matter and somatic cell count in milk. In addition to changing the frequency of milking, the calculation also took into account other factors such as: order of lactation $(1,2$, and $\geq 3)$ and duration of lactation (100 days, 101-200 days, 201300 days, and more than 300 days). Somatic Cell Count (SCC), expressed in thousands per $\mathrm{mL}$ of milk, were transformed into Excel ${ }^{\circledR}$ program for the natural logarithm (NLSCC), which allowed to meet the conditions for normal itemization of this trait. The mean value $(\bar{x})$ and standard deviation (SD) were calculated. The significance of differences between groups were calculated by one-way analysis of variance using Duncan's multiple range test in the Statistica ${ }^{\circledR} 10$ PL (StatSoft, Inc. 2011).

\section{Results and discussion}

Table 1 shows the effects of frequency of daily milking on the performance, the somatic cell count (NLSCC) and the chemical composition of milk. It was verified statistically $(\mathrm{P} \leq 0.01)$ that a significant increase in daily yield occurred - when milked twice a day when milked three times a day. Research conducted by other authors also showed an increase in milk production by increasing frequency of daily milking. The analyses conducted by Bogucki et al. (2009) showed an increase of milk yield at a level of $10.7 \%$, the studies by Knapczyk et al. (2007) reported a slightly lower increase of milk yield at a level of $7 \%$. In our own study, after shifting to a threetimes a day milking schedule, we noticed a slight increase in milk fat content $(0.03 \%)$. In contrast, protein and dry matter in milk was reduced respectively by $0.24 \%$ and $0.06 \%(\mathrm{P} \leq 0.01)$. Similarly, in studies by Bogucki et al. (2009) increasing the frequency of milking caused a decrease in protein content $(0.11 \%)$ and an increase in fat content $(0.28 \%)$ as well as slightly lowering the value of NLSCC. Campos et al. (1994) in studies on milking three

Table 1. Effect of milking frequency on daily yield, quality and composition of milk

\begin{tabular}{cccccccc}
\hline \multirow{2}{*}{ Milking frequency } & \multirow{2}{*}{$\mathrm{n}$} & Daily milk yield, kg & Fat, \% & Protein, \% & Dry matter, \% & NLSCC \\
\hline \multirow{2}{*}{ Two times milking } & $\bar{x}$ & \multirow{2}{*}{764} & $30.90^{\mathrm{A}}$ & 3.92 & $3.44^{\mathrm{A}}$ & $12.98^{\mathrm{A}}$ & 3.24 \\
& $\mathrm{SD}$ & & 9.32 & 0.77 & 0.40 & 0.98 & 0.99 \\
\hline \multirow{2}{*}{ Three times milking } & $\bar{x}$ & \multirow{2}{*}{808} & $34.77^{\mathrm{A}}$ & 3.95 & $3.38^{\mathrm{A}}$ & $12.74^{\mathrm{A}}$ & 3.22 \\
& SD & & 9.94 & 0.63 & 0.29 & 0.71 & 1.19 \\
\hline
\end{tabular}

$\bar{x}$ - mean value, SD - standard deviation, NLSCC - natural logarithm Somatic Cell Count

Average values in columns identified with the same letters are significantly different: large letters at $\mathrm{P} \leq 0.01$ 
times per day and twice per day of Holstein-Friesian and Jersey breeds reported an increase in protein and fat content in milk. In our own study (Table 1), the average value of the natural logarithm of the number of somatic cells (NLSCC) had a downward trend at milking three times a day.

In Table 2 , there was increase $(\mathrm{P} \leq 0.01)$ in daily milk yield of heifers of $1.59 \mathrm{~kg}$ and cows in the second of $6.09 \mathrm{~kg}$ and $\geq$ third lactation of $4.16 \mathrm{~kg}$. Increasing milking times affected multiparous cows more effectively than heifers. In the case of the youngest cows daily gains of about $5.5 \%$ were recorded while with the older cows from 12 to $19.18 \%$. This is confirmed by Allen et al. (1986), which indicate that the impact of increased milking times were more favorable for multiparous cows. The results presented by Bogucki et al. (2009) indicate that cows which are in the first lactation and milked three times daily have milk yield increase of approximately $25 \%$, whereas in older cows of $11 \%$. Most dairy cows throughout the world are milked twice-daily. In intensive dairying systems, however, it is not uncommon to increase milking frequency to between 3 and 6 times daily to increase milk production. Reducing milking frequency is much less common; however, once-daily milking of dairy cows, practiced either strategically during certain parts of the lactation or for the entire lactation, is not uncommon in key dairying countries where less emphasis is placed on milk production per cow (Stelwagen et al. 2013).
Depending on the frequency of milking, the protein content in milk (Table 2) varied in cows in first lactation - from 3.44 to $3.39 \%$. In research by Bogucki et al. (2011), a decreasing trend (at milking three times daily) was also observed in groups of cows being in the second, third and over a third lactation $(\mathrm{P} \leq 0.01)$. In another work by Bogucki et al. (2009) only in the second lactation the cited authors observed a slight increase in protein content (from 3.47 to $3.49 \%$ ) in the milk of cows milked twice. In our own study, the fat content in the milk increased in successive age groups of cows (Table 2). Bogucki et al. (2011) analyzed the impact of changes in the organization of milking within the age group found no statistically significant differences in fat content in milk, it showed higher fat content in the milk of cows milked three times daily. Soberon et al. (2011) stated that early lactation increased milking frequency has the potential to increase milk yield on commercial dairy farms.

Analyzing the number of somatic cells in milk (NLSCC) (Table 2) a slight drop in number was recorded in milking three times a day $(2$ and $\geq 3$ lactations). Significant differences $(\mathrm{P} \leq 0.05)$ on the number of somatic cells in milk were recorded only in cows in the first lactation where NLSCC value decreased from 3.17 to 3.01 when milking twice. In the study by Bogucki et al. (2009), after increasing the frequency of milking (from twice to three times) in all lactation groups, he observed a slight, statistically insignificant decrease in their number.

Table 2. Effect of milking frequency on daily yield, quality and composition of the milk, taking into account the subsequent lactation

\begin{tabular}{|c|c|c|c|c|c|c|c|c|}
\hline \multicolumn{2}{|c|}{ Milking frequency } & Lactation & $\mathrm{n}$ & Daily milk yield, kg & Fat, $\%$ & Protein, $\%$ & Dry matter, $\%$ & NLSCC \\
\hline $\begin{array}{l}\text { Two times } \\
\text { milking }\end{array}$ & $\begin{array}{c}\bar{x} \\
\mathrm{SD}\end{array}$ & \multirow{2}{*}{ l } & 386 & $\begin{array}{c}28.89^{\mathrm{A}} \\
6.81\end{array}$ & $\begin{array}{l}3.88 \\
0.69\end{array}$ & $\begin{array}{c}3.44^{\mathrm{A}} \\
0.39\end{array}$ & $\begin{array}{l}13.00^{\mathrm{A}} \\
0.93\end{array}$ & $\begin{array}{l}3.01^{\mathrm{a}} \\
0.91\end{array}$ \\
\hline $\begin{array}{c}\text { Three times } \\
\text { milking }\end{array}$ & $\begin{array}{c}\bar{x} \\
\mathrm{SD} \\
\end{array}$ & & 367 & $\begin{array}{c}30.48^{\mathrm{A}} \\
6.57 \\
\end{array}$ & $\begin{array}{l}3.89 \\
0.63 \\
\end{array}$ & $\begin{array}{c}3.39^{\mathrm{A}} \\
0.26 \\
\end{array}$ & $\begin{array}{c}12.72^{\mathrm{A}} \\
0.67 \\
\end{array}$ & $\begin{array}{l}3.17^{\mathrm{a}} \\
0.87 \\
\end{array}$ \\
\hline $\begin{array}{l}\text { Two times } \\
\text { milking }\end{array}$ & $\begin{array}{c}\bar{x} \\
\mathrm{SD}\end{array}$ & \multirow{2}{*}{2} & 218 & $\begin{array}{c}31.76^{\mathrm{B}} \\
10.99 \\
\end{array}$ & $\begin{array}{l}3.92 \\
0.79 \\
\end{array}$ & $\begin{array}{c}3.49^{\mathrm{B}} \\
0.41 \\
\end{array}$ & $\begin{array}{c}12.99^{\text {в }} \\
1.01\end{array}$ & $\begin{array}{l}3.41 \\
1.00 \\
\end{array}$ \\
\hline $\begin{array}{c}\text { Three times } \\
\text { milking }\end{array}$ & $\begin{array}{c}\bar{x} \\
\mathrm{SD} \\
\end{array}$ & & 244 & $\begin{array}{c}37.85^{\mathrm{B}} \\
9.59^{-} \\
\end{array}$ & $\begin{array}{l}3.96 \\
0.64 \\
\end{array}$ & $\begin{array}{l}3.38^{\mathrm{B}} \\
0.29 \\
\end{array}$ & $\begin{array}{c}12.75^{\mathrm{B}} \\
0.72 \\
\end{array}$ & $\begin{array}{l}3.24 \\
1.02 \\
\end{array}$ \\
\hline $\begin{array}{l}\text { Two times } \\
\text { milking }\end{array}$ & $\begin{array}{c}\bar{x} \\
\mathrm{SD} \\
\end{array}$ & \multirow{2}{*}{$\geq 3$} & 160 & $\begin{array}{c}33.88^{\mathrm{c}} \\
10.42 \\
\end{array}$ & $\begin{array}{l}4.01 \\
0.87\end{array}$ & $\begin{array}{c}3.40^{\mathrm{C}} \\
0.38 \\
\end{array}$ & $\begin{array}{c}12.95^{\mathrm{C}} \\
1.03 \\
\end{array}$ & $\begin{array}{l}3.56 \\
1.06 \\
\end{array}$ \\
\hline $\begin{array}{l}\text { Three times } \\
\text { milking }\end{array}$ & $\begin{array}{l}\bar{x} \\
\mathrm{SD}\end{array}$ & & 197 & $\begin{array}{c}38.04^{\mathrm{C}} \\
12.01\end{array}$ & $\begin{array}{l}4.12 \\
0.63\end{array}$ & $\begin{array}{c}3.37^{\mathrm{C}} \\
0.35\end{array}$ & $\begin{array}{c}12.77^{\mathrm{C}} \\
0.77^{\circ}\end{array}$ & $\begin{array}{l}3.30 \\
0.99\end{array}$ \\
\hline
\end{tabular}

$\bar{x}$ - mean value, SD - standard deviation, NLSCC - natural logarithm Somatic Cell Count

Average values in columns identified with the same letters are significantly different: large letters at $\mathrm{P} \leq 0.01$; small letters at $\mathrm{P} \leq 0.05$ 
Table 3 shows the effect of milking frequency on daily performance, quality, composition of the milk, taking into account the lactation period. A significant statistical $(\mathrm{P} \leq 0.01)$ increase was reported in daily milk yield in all the analyzed subsequent periods of lactation in milking three times. In case of beginning-lactation cows, daily yield increased. In subsequent periods of lactating, the growth was at the level of $10 \%-20 \%$. In terms of the fat content of milk, a decrease was observed in lactation groups (201-300 days and >300 days) in cows milked twice daily. In the remaining periods of lactation ( $\leq 100$ days, 101-200 days), increases were reported in cows milked three times. Differences were found $(\mathrm{P} \leq 0.01 ; \mathrm{P} \leq 0.05)$ in lactation groups of $\leq 100$ days and $>300$ days. Analyzing the protein content of milk, an increase was observed in the group of younger cows $(\leq 100$ days $)$ milked three times. In other lactation periods (101-200 days, 201-300 days and $>300$ days) protein content in milk was significantly higher $(\mathrm{P} \leq 0.01)$ in the case 2 milkings per day. Sawa and Oler (1999) emphasized that the increase of the protein content with an increase in somatic cells is disadvantageous with regard to the milk processing industry because of decreasing share of the most valuable protein - casein while whey proteins share is increasing.

In our own study, it was observed that increasing milking frequency preferably affected quality of milk. We observed a slight decrease in the number of somatic cells (NLSCC) when the cows were milked three times. Only in the group of cows from 101 to 200 days of lactation NLSCC value was lower in the case of cows milked twice. Opposite, in cows starting lactation $(\leq 100 \mathrm{~d})$ the NLSCC value was the same for both two and three milkings per day. Pytlewski et al. (2013) paid attention to the order

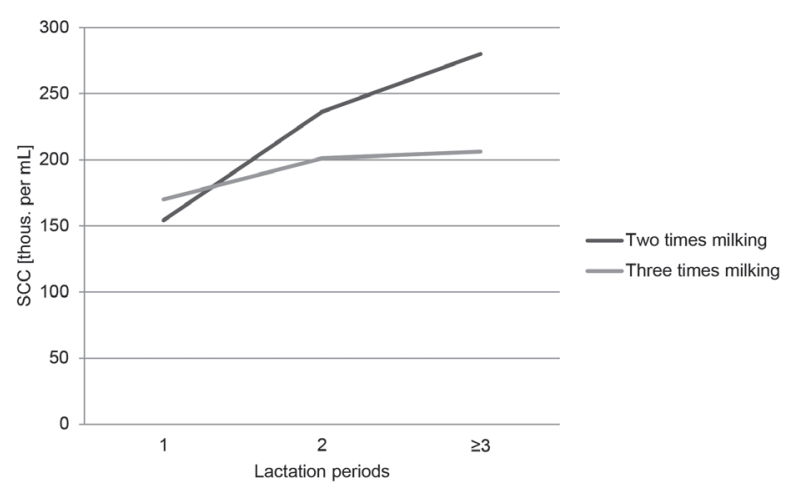

Figure 1. Somatic cells count in terms of subsequent lactations of procedures involved in preparing the teats and udder for milking. A smaller number of somatic cells in milk was found when the first operation before actual milking was pre-milking and next cleaning teats and udder. The first aspect dipping the teats in the washing solution (preddiping), and only later pre-milking and teats drying before actual milking. Sharma et al. (2011) point out that the number of cellular elements in milk has become one of the key diagnostic criteria and is used to monitor the health status of the mammary gland. It is particularly important for farmers and milk producers to assure that milk and its products enjoy ongoing popularity and should always be of the highest quality which in turn depends on the quality of raw milk (Cioch et al., 2013).

The Figure 1 and Figure 2 show the quality of raw milk assessment taking into account the subsequent lactation and milking period depending on frequency of milking. The analysis of data shows that the somatic cell count (in thous. per $\mathrm{mL}$ ) was lower in the group of cows milked three times. Minor differences between analyzed milking systems and the average number of somatic cells can attest to the high quality of milk produced and high hygiene standards of milking at the tested farm.

\section{Conclusion}

It should be noted that increasing the frequency of milking had a significant effect both on the milk yield $(\mathrm{P} \leq 0.01)$, causing its substantial increase, as well as the cytological quality of milk. Milking three times a day instead of twice a day resulted in an increase in daily milk yield in all analysed lactations.

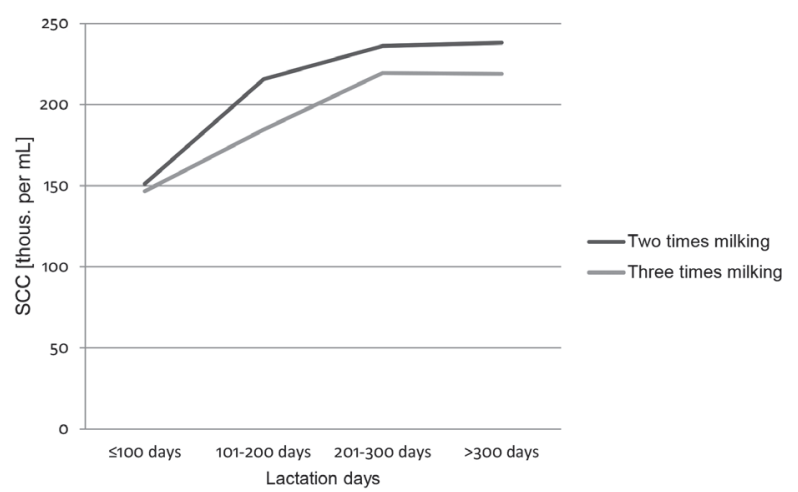

Figure 2. Somatic cells count in terms of subsequent lactation periods 


\section{Utjecaj učestalosti mužnje na količinu, kemijski sastav i kvalitetu mlijeka}

\section{Sažetak}

Cilj ovog istraživanja bio je usporediti dnevnu količinu mlijeka, sastav mlijeka i broj somatskih stanica nakon povećanja učestalosti mužnje s dva na tri puta. Studija je također uključila i druge čimbenike: redoslijed laktacije $(1,2, \geq 3)$ i razdoblje laktacije (do 100 dana, 101-200 dana, 201-300 dana, i više od 300 dana). Zaključno, treba napomenuti da povećanje učestalosti mužnje krava ima pozitivan učinak i na količinu mlijeka $(P \leq 0,01)$, što uzrokuje značajno povećanje, kao i na citološku kvalitetu proizvedenog mlijeka. Broj somatskih stanica $(1000 / \mathrm{mL})$ bio je manji u skupini krava koje su bile na mužnji tri puta. Svi podaci prikupljeni su iz sustava dokumentacije SYMLEK, osigurane iz zajedničke dokumentacije uzgojne grane privrede, koju vodi Poljsko udruženje stočara i proizvođača mlijeka (PFHBiPM). Analiza je uključivala: dnevnu količinu, količinu masti, proteina, suhe tvari kao i broj somatskih stanica u mlijeku.

Ključne riječi: krave, mlijeko, somatske stanice, učestalost mužnje

\section{References}

1. Allen, D.B., Depeters, E.J., Laben, R.C. (1986): Three times a day milking: effects on production, reproduction efficiency and udder health. Journal of Dairy Science 69, 1441-1448. https://doi.org/10.3168/jds.S0022-0302(86)80553-7

2. Barłowska, J., Jarosińska, A., Wolanciuk, A., Kędzierska -Matysek, M. (2012): Jakość mleka towarowego pozyskiwanego w gospodarstwach stosujących różne systemy doju. Roczniki Naukowe Polskiego Towarzystwa Zootechnicznego 8 (1), 31-38.

3. Bogucki, M., Sawa, A., Neja, W. (2011): Wpływ zmiany organizacji doju na wydajność krów i jakość mleka. Roczniki Naukowe Polskiego Towarzystwa Zootechnicznego 7 (1), 29-35.

4. Bogucki, M., Sawa, A., Ryduchowski, F. (2009): Wpływ częstotliwości doju na wydajność, skład chemiczny i jakość mleka. Roczniki Naukowe Polskiego Towarzystwa Zootechnicznego 5 (3), 29-37.

5. Campos, M.S., Wilcox, C.J., Head, H.H., Weeb, D.W., Hayen, J. (1994): Effects on production of milking three times daily on first lactation Holsteins and Jerseys in Florida. Journal of Dairy Science 77, 770-773. https://doi.org/10.3168/jds.S0022-0302(94)77011-9
6. Capuco, A.V., Wood, D.L., Baldwin, R., Mcleod, K., Paape, M.J. (2001): Mammary cell number, proliferation, and apoptosis during a bovine lactation: relation to milk production and effect of BST. Journal of Dairy Science 84, 2177-2187. https://doi.org/10.3168/jds.S0022-0302(01)74664-4

7. Cioch, B., Czerniawska-Piątkowska, E., Chociłowicz E. (2013): Comparision of milk composition depending on system of milking. Folia Pomer. Univ. Technol. Stetin., Agric., Aliment., Pisc., Zootech. 305 (27), 7-12.

8. Czerniawska-Piątkowska, E., Gralla K., Szewczuk, M., Chociłowicz, E. (2012): The comparison of yield, composition and quality of cow milk depending on twicea-day and four-times-a-day milking. Acta Scientiarum Polonorum Zootechnica 11 (4), 21-30.

9. Hale, S.A., Capuco, A.V., Erdman, R.A. (2003): Milk yield and mammary growth effects due to increased milking frequency during early lactation. Journal of Dairy Science 86, 2061-2071. https://doi.org/10.3168/jds.S0022-0302(03)73795-3

10. Knapczyk, K., Wołkowski, T., Szarek, J., Adamczyk, K. (2007): Wpływ częstotliwości doju krów na wydajność mleczną, procentową zawartość białka i liczbę komórek somatycznych. Materiały LXXII Zjazdu PTZ, Warszawa [In Polish].

11. Pytlewski, J., Antkowiak, I., Waliszewska, M., Skrzypek, R. (2013): Wpływ zmiany kolejności procedur przeddojowych na jakość higieniczną mleka. Nauka Przyroda Technologie 7 (4), 56.

12. Sawa, A., Oler, A. (1999): Wpływ zapalenia wymienia i wybranych czynników środowiskowych na wydajność, skład i jakość mleka. Zesz. Nauk. Prz. Hod. 44, 225233.

13. Sharma, N., Singh, N.K., Bhadwal, M.S. (2011): Relationship of somatic cell count and mastitis: an overview. Asian-Australasian Journal of Animal Sciences 24 (3), 429-438.

14. Soberon, F., Ryan, C.M., Nydam, D.V., Galton, D.M., Overton, T.R. (2011) The effects of increased milking frequency during early lactation on milk yield and milk composition on commercial dairy farms. Journal of Dairy Science 94, 4398-4405. https://doi.org/10.3168/jds.2010-3640

15. StatSoft, Inc. (2011) STATISTICA ${ }^{\circledast}$ (data analysis software system), version 10. www.statsoft.com.

16. Stelwagen, K., Phyn, C.V.C., Davis, S.R., Guinard-Flament, J., Pomiès, D., Roche, J.R., Kay, J.K., (2013): Invited review: reduced milking frequency: milk production and management implications. Journal of Dairy Science 96, 3401-3413. https://doi.org/10.3168/jds.2012-6074

17. Wall, E.H., McFadden, T.B. (2008): Use it or lose it: enhancing milk production efficiency by frequent milking of dairy cows. Journal of Animal Science 86, 27-36. https://doi.org/10.2527/jas.2007-0318

18. Wołkowski, T., Szarek, J., Wegglarzy, K. (2003): Poprawa wydajności mlecznej u krów poprzez zwiększenie częstotliwości doju i stosowanie somatotropiny. Zesz. Nauk. Prz. Hod. 67, 21-27. 